\title{
Treetop shelter of a Neotropical River Otter cub (Lontra longicaudis - Carnivora: Mustelidae) in an Amazonian flooded forest
}

Pedro Manuel Ribeiro Simões dos SANTOS ${ }^{1}$, Valdely Ferreira KINUPP², Alexandre COLETTO-SILVA ${ }^{3}$

\section{ABSTRACT}

The finding of a Neotropical river otter (Lontra longicaudis) cub occupying a shelter in a hollowed treetop is reported. The observation was made in a seasonally flooded forest in Central Amazonia, during the high water peak of the annual inundation cycle. A literature review indicates that this is the first description of a shelter of the species, both in a hollowed tree and in Amazonia. This observation can indicate a strong relationship between the species' breeding cycle with the annual dynamics of Amazonian rivers. We discuss potential advantages and disadvantages of breeding when water level is high.

\section{KEYWORDS}

Amazonia, flooded forest, Lontra longicaudis, shelter use, seasonal water level variation

\section{Abrigo em copa de árvore de filhote de lontra Neotropical (Lontra longicaudis - Carnivora: Mustelidae) em floresta inundável amazônica}

\begin{abstract}
RESUMO
É relatada a observação de um filhote de lontra (Lontra longicaudis) ocupando um abrigo em uma cavidade na copa de uma árvore. A observação foi feita em uma floresta inundada na Amazônia Central, no pico de cheia do ciclo anual de inundação. A revisão da literatura revela que esta é a primeira descrição de um abrigo desta espécie em uma cavidade de árvore na natureza e na Amazônia. Tal observação pode indicar uma forte relação entre o ciclo reprodutivo da espécie e a dinâmica anual dos rios amazônicos. Discutimos vantagens e desvantagens potenciais da reprodução na época da cheia.
\end{abstract}

\section{PALAVRAS-CHAVE}

Amazônia, floresta inundada, Lontra longicaudis, uso de abrigo, variação sazonal do nível da água

\footnotetext{
1 Bolsista DTI-CNPq, Universidade do Estado do Amazonas, Centro de Estudos Superiores de Tefé. Rua Marechal Deodoro, 802, 0laria, 69470-000 Tefé AM, Brasil. pedromrssantos@hotmail.com 2 Bolsista de Doutorado - CNPq, Departamento de Horticultura e Silvicultura, Faculdade de Agronomia, Universidade Federal do Rio Grande do Sul. Av. Bento Gonçalves 9.500, Bairro Agronomia, 91540-000 Porto Alegre RS, Brasil. valkinupp@yahoo.com.br

${ }^{3}$ Bolsista PCI - CNPq, Instituto Nacional de Pesquisas da Amazônia, Coordenação de Pesquisas em Ciências Agronômicas. Caixa Postal 4167, ACF Vieiralves, 69053-971 Manaus AM, Brasil. alexbelha@hotmail.com
} 
Like most other aspects of the biology and ecology of wildranging Neotropical river otters (Lontra longicaudis), reproduction is virtually unknown, especially in Amazonia (Best, 1984; Leite, 1994; Rosas et al. 1991; Rosas, 2004). Junk \& Silva (1997) suggested that, in seasonally flooded forests, breeding takes place year-round, peaking at the low-water season, which agrees with Duplaix (1980) for Surinam, but published first-hand data are scant or null. Likewise, although Larivière (1999) states that the species can use hollow logs or trees, he gives no details or references, and the literature seems to describe only shelters in river margins, in extra-Amazonian sites (e.g., Pardini \& Trajano, 1999; Quadros \& Monteiro-Filho, 2002; Kasper et al., 2004). We report an otter cub found inside a natural tree cavity in Central Amazonia (Anavilhanas Ecological Station, lower Rio Negro, Amazonas, Brazil). This may be the first published breeding record of Neotropical river otters in Brazilian Amazonia, and also of a shelter located on the top of a living, standing tree, of any otter species.

The Anavilhanas Ecological Station includes the Anavilhanas Archipelago (A.A.), one of the largest fluvial archipelagos in the world, with approximately 400 islands spread through an area of 100,000 ha on the Rio Negro. The A.A. is entirely covered by "igapó", an Amazonian forest seasonally flooded by black, nutrient-poor, water (Prance, 1980). The frequency and duration of inundation are of great ecological importance, since they determine an aquatic and a terrestrial phase of variable spatiotemporal extent throughout the year, with profound effects on the floodplain biota (Junk et al., 1989). At the A.A., water level fluctuates between about 8 and $12 \mathrm{~m}$ annually, in a predictable pattern, with minima and maxima in OctoberDecember and June-July, respectively (Figure 1); at the flood peak, the forest floor is completely submerged between 1 and $20 \mathrm{~m}$ (Goulding et al., 1988).

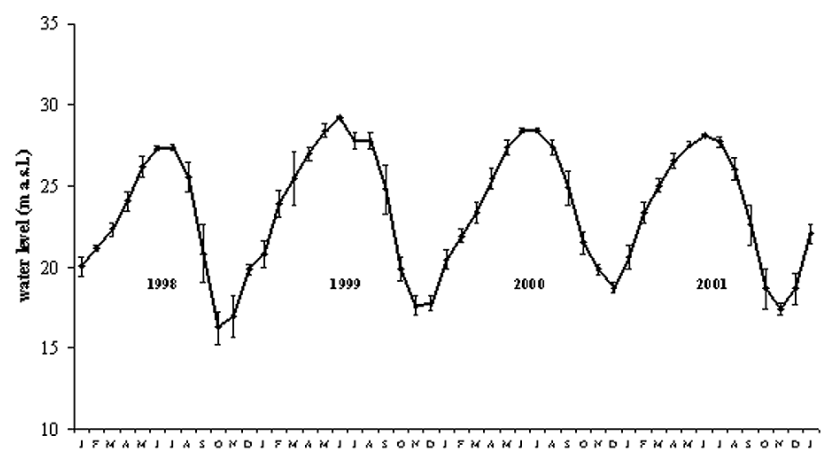

Figure 1 - Annual variation of water level at the Manaus harbour at the Rio Negro, years 1998-2001 (meters above sea level, a.s.l.). For each month, the average water level and standard deviation of daily recorded data are represented. Manaus lies $100 \mathrm{~km}$ downstream from the Anavilhanas Archipelago (A.A.); at the A.A., water level varies similarly, but with a few days advance (Piedade, M.T.F., personal communication). Data provided by Portobras, Manaus.
The otter shelter and cub were found on 10 July 2001 (244'20"S, 6046'30"W), on a "matamatá" tree (Eschweilera tenuifolia (O. Berg) Miers, Lecythidaceae) that was partially submerged to a depth of $8 \mathrm{~m}$. E. tenuifolia occurs in monodominant stands that are somewhat isolated, and occupy the lowest-lying terrains, flooded for the longest time (Mori, 2001). At the time of our visit, only treetops emerged from the water level surface (Figure 2A and 2B). The shelter was located on the top of the tree trunk, which was partially hollowed, forming an exposed cavity. No special stuffing was lining the shelter; it was covered only with material resulting from the disaggregation of the trunk, and with roots of Clusia sp. hemiepiphytes (Figure 2C). A single vocalizing Neotropical river otter cub was inside (Figure 2D). The lack of a flattened tail or spots visible from above, along with the size of the cavity itself, allowed its unambiguous distinction from a cub of the much larger giant river otter (Pteronura brasiliensis), the only otter species in the region which could hypothetically have been confused with the Neotropical otter (Emmons \& Feer, 1997). We left the site and returned after two hours, but no sign of the cub or adult presence or recent activity was found, as well as of predation or any other interference.

On 18 July 2001, we revisited the shelter and no otters were observed. Nevertheless, some of the cub's measures could be inferred, based on the measurement of a Clusia sp. root that had been photographed close to the animal in the first visit, and was found again when the shelter was revisited. They are: head: 6.7 $\mathrm{cm}$; head and body: $26.8 \mathrm{~cm}$; tail: $11.7 \mathrm{~cm}$; total length: 38.5 $\mathrm{cm}$. We also made some measurements of the tree: total height: $13 \mathrm{~m}$; circumference at $8 \mathrm{~m}$ height: $1.64 \mathrm{~m}$; and of the shelter: depth: $0.20 \mathrm{~m}$; distance from border of cavity to water at maximum water level: $1.20 \mathrm{~m}$.
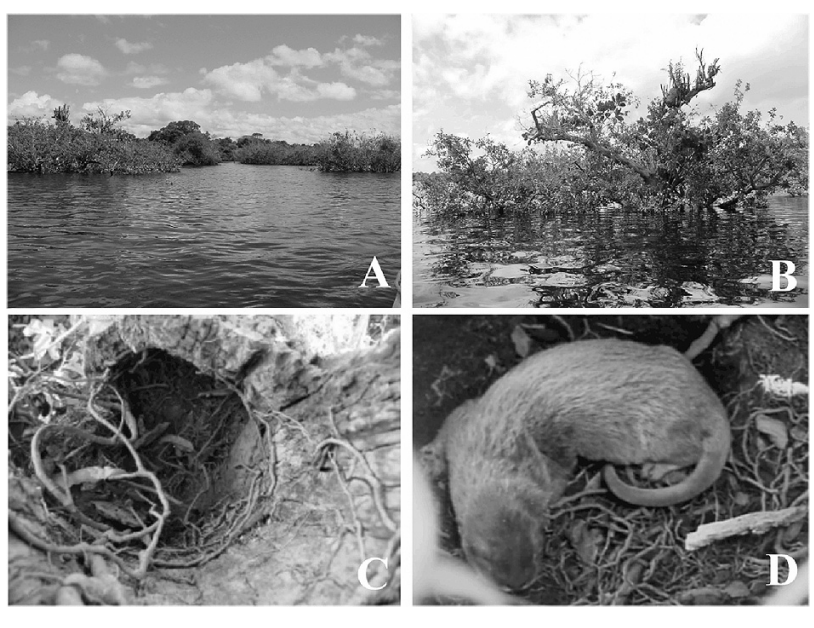

Figure 2 - A) Stand of "matamatá" (Eschweilera tenuifolia) in the "igapó" forest of the Anavilhanas Archipelago (A.A.). B) The "matamatá" tree where the otter shelter was located. C) The shelter seen from above. D) The neotropical river otter (Lontra longicaudis) cub. Photos by Alexandre Coletto da Silva $(A, B, C)$ and Valdely Ferreira Kinupp (D). 
If the mother did not remove the cub from the shelter in response to our presence, like giant river otters do (Duplaix, 1980), the cub observed at the A.A. likely started exploring the surrounding habitat at the time of our visits, as suggested by its absence from the tree cavity later the first day, and on the second visit. Captive Neotropical river otters start aquatic activity at ca. 74 days (Larivière, 1999); assuming that this also happens in nature, we can infer that the adult female gave birth by the end of May. Data from the A.A. (marks left by the water on "igapó" trees), and from the Rio Negro near Manaus (Figure 1), indicate that the birth occurred when water level was less than one meter lower than at the time of our first visit (when we found the shelter and the cub). Subsequently, water level reached its maximum some 20 days before that visit, remained constant until the visit happened, and had already dropped $30-50 \mathrm{~cm}$ on our second visit. This would make access to the shelter increasingly difficult for the cub and the adult if the birth had occurred little after it did, especially since the annual water level drop is quicker than its rise.

In any case, all the period spanning the birth and the inception of the cub's independent life likely happened when water level was maximum, or nearly so. This makes us suggest that Neotropical river otters can adjust their reproductive cycle to the annual river dynamics in Amazonian seasonally flooded forests, via delayed implantation or another reproductive strategy - see Blacher (1994); Jacome \& Parera (1995); Larivière (1999) and Arcila \& Ramírez (2004).

Water level is the environmental factor that varies more appreciably and poses more ecological and behavioural constraints to the biota that inhabit seasonally flooded forests (Ayres, 1993). Since it is most constant and predictable at the peak of the aquatic phase (Figure 1), giving birth at this time of the year may be advantageous to otters and other animals that possess the plasticity required to adapt to a variety of denning substrates, especially if those species can couple the timing of reproduction with the relevant environmental factors, as several otter species do elsewhere. In detailed studies carried out in southern Brazil, Pardini \& Trajano (1999) and Quadros \& Monteiro-Filho (2002) found that Neotropical river otters favoured shelters located high in river banks, and inferred a correlation with vulnerability to flooding. In Amazonian flooded forests, the risk of flooding can likewise be minimized by choosing high tree tops, at a time when no exposed banks are available as shelters.

\section{ACKNOWLEDGEMENTS}

The authors express their thanks to Cristina Motta Bührnheim, Susana Ketelhut, Maria Teresa Piedade, Fernando Rosas, Tania Sanaiotti, Vera Maria Ferreira da Silva, and anonymous reviewers, for their valuable assistance and comments; to Helen Waldemarin for providing literature; to Oswaldo
("Comandante Roque") for providing transportation to the area; to FCT (Fundação para a Ciência e a Tecnologia, Ministério da Ciência e do Ensino Superior, Portugal)/PRAXIS XXI/Quadro Comunitário de Apoio, CAPES (Coordenação de Aperfeiçoamento de Pessoal de Nível Superior, Ministério da Educação, Brazil), and CNPq (Conselho Nacional de Desenvolvimento Científico e Tecnológico, Ministério da Ciência e Tecnologia, Brazil) for scholarships granted to P. Santos, V. Kinupp, and A. Coletto, respectively.

\section{LITERATURE CITED}

Arcila, D.A.; Ramírez, M. 2004. Captive reproduction of the neotropical otter in the Santa Fe Zoological Park in Medellín, Colombia. IUCN Otter Spec. Group Bull., 21(1): 16-18.

Ayres, J.M. 1993. As Matas de Várzea do Mamirauá - Médio Rio Solimões. Série Estudos de Mamirauá, volume I. Sociedade Civil Mamirauá e CNPq/PTU. Rio de Janeiro, 124 p.

Best, R.C. 1984. The aquatic mammals and reptiles of the Amazon. In: The Amazon: limnology and landscape ecology of a mighty tropical river and its basin. Sioli, H. (Ed.), Dr. W. Junk Publishers, The Hague. p. 371-412.

Blacher, C. 1994. Strategic reproduction of Lutra longicaudis. IUCN Otter Spec. Group Bull., 9: 6.

Duplaix, N. 1980. Observations on the ecology and behavior of the giant river otter Pternoura brasiliensis in Suriname. Rev. Ecol. (Terre Vie), 34: 495-620.

Emmons, L.H.; Feer, F. 1997. Neotropical rainforest mammals: a field guide. ( $\left.2^{\text {nd }} \mathrm{ed}\right)$. The University of Chicago Press, Chicago and London, $307 \mathrm{p}$.

Goulding, M.; Carvalho, M.L.; Ferreira, E.G. 1988. Rio Negro: rich life in poor water. SPB Academic Publishing, The Hague, 200 p.

Jacome, L.; Parera, A., 1995. Neotropical river otter, Lutra longicaudis, breeding under captive conditions in Buenos Aires Zoo, Argentina. IUCN Otter Spec. Group Bull., 12: 34-36.

Junk, W.J., Bailey, P.B.; Sparks, R.E., 1989. The flood pulse concept in river-floodplain systems. In: Proc. Int. Large River Symp. (LARS). Dodge, D. P. (Ed.). Can. Spec. Publ. Fish. Aquat. Sci., 106: 110-127.

Junk, W.J.; Silva, V.M.F., 1997. Mammals, reptiles and amphibians. In: The central Amazon floodplain: ecology of a pulsing system. Junk, W. J. (Ed.), Springer-Verlag, Berlin, Heidelberg and New York. p. 409-417.

Kasper, C.B.; Feldens, M.J.; Salvi, J.; Grillo, H.C.Z. 2004. Estudo preliminar sobre a ecologia de Lontra longicaudis (Olfers) (Carnivora, Mustelidae) no Vale do Taquari, Sul do Brasil. Revista Brasileira de Zoologia, 21(1): 65-72.

Larivière, S. 1999. Lontra longicaudis. Mammal. Spec., 609: 1-5.

Leite, Y.L.R. 1994. Lontra Lutra longicaudis (Olfers, 1818). In: Livro vermelho dos mamiferos brasileiros ameaçados de extinção. Fonseca, G.A.B. da et al. (Eds.), Fundação Biodiversitas, Belo Horizonte. p. 347-352. 
Mori, S.A. 2001. A família da castanha-do-Pará: símbolo do Rio Negro. In: Florestas do Rio Negro. Oliveira, A. A.; Daly, D. (Eds.), Companhia das Letras / UNIP, São Paulo. p. 119-142.

Pardini, R.; Trajano, E. 1999. Use of shelters by the neotropical river otter (Lontra longicaudis) in an Atlantic forest stream, southeastern Brazil. J. Mammal., 89(2): 600-610.

Prance, G.T. 1980. A terminologia dos tipos de florestas amazônicas sujeitas à inundação. Acta Amazonica, 10(3): 495-504.

Quadros, J.; Monteiro-Filho, E.L.A. 2002. Sprainting sites of the neotropical otter Lontra longicaudis, in an Atlantic forest area of southern Brazil. J. Neotrop. Mammal., 9(1): 39-46.
Rosas, F.C.W. 2004. Lontra, Lontra longicaudis (Carnivora: Mustelidae). In: História natural, ecologia e conservação de algumas espécies de plantas e animais da Amazônia. Cintra, R. (Coord.), EDUA, Manaus. p. 261-264.

Rosas, F.C.W., Colares, E.P.; Colares, I.G.; Silva, V.M.F. 1991. Mamíferos aquáticos da Amazônia brasileira. In: Bases científicas para estratégias de preservaçāo e desenvolvimento da Amazônia: fatos eperspectivas. Val, A.L.; Figliuolo, R.; Feldberg, E. (Eds.), INPA, Manaus. p. 403-411.

Recebido em 06/10/2006

Aceito em 10/04/2007 